\title{
The Effect of Curcumin and Virgin Coconut Oil Towards Cytokines Levels in COVID-19 Patients at Universitas Sebelas Maret Hospital, Surakarta, Indonesia
}

\author{
Hartono ${ }^{1,2 *}$, B Suryawati ${ }^{3}$, Y Sari ${ }^{4}$, A Avicena ${ }^{2}$, Maryani ${ }^{3}$, C Sukmagautama ${ }^{2}$, H Apriningsih ${ }^{2}$, L Shofiyah ${ }^{2}$, RGH \\ Novika ${ }^{5}$, NJ Wahidah ${ }^{5}$, NY Rahmawati ${ }^{6}$, ANM Ansori ${ }^{7}$, L Sumarno ${ }^{8}$
}

Hartono ${ }^{1,2 *}$, B Suryawati ${ }^{3}, Y$ Sari ${ }^{4}$, A Avicena' ${ }^{2}$, Maryani ${ }^{3}$, C Sukmagautama ${ }^{2}$, H Apriningsih ${ }^{2}$, L Shofiyah ${ }^{2}$, RGH Novika ${ }^{5}$, NJ Wahidah $^{5}$, NY Rahmawati ${ }^{6}$, ANM Ansori ${ }^{7}$, L Sumarno ${ }^{8}$

'Department of Physiology, Faculty of Medicine, Universitas Sebelas Maret, Surakarta, Indonesia

${ }^{2}$ Universitas Sebelas Maret (UNS) Teaching Hospital, Surakarta, Indonesia ${ }^{3}$ Department of Microbiology, Faculty of Medicine, Universitas Sebelas Maret, Surakarta, Indonesia

${ }^{4}$ Department of Parasitology, Faculty of Medicine, Universitas Sebelas Maret, Surakarta, Indonesia

${ }^{5}$ Midwifery Study Program, Faculty of Medicine, Universitas Sebelas Maret, Indonesia

${ }^{6}$ Doctoral Program of Medical Science, Faculty of Medicine, Universitas Airlangga Surabaya, Indonesia

${ }^{7}$ Doctoral Program of Veterinary Science, Faculty of Veterinary Medicine, Universitas Airlangga, Surabaya, Indonesia

${ }^{8}$ National Research and Innovation Agency, Jakarta, Indonesia

\section{Correspondence}

\section{Hartono}

Department of Physiology, Faculty of Medicine, Universitas Sebelas Mare (UNS) Teaching Hospital, Surakarta, INDONESIA.

E-mail: hartono65@staff.uns.ac.id

Orcid: https://orcid.org/0000-0002-5947-9357 History

- Submission Date: 18-10-2021;

- Review completed: 11-12-2021;

- Accepted Date: 03-01-2022.

DOI : 10.5530/pj.2022.14.27

Article Available online http://www.phcogj.com/v14/i1

\section{Copyright}

(C) 2022 Phcogj.Com. This is an open access article distributed under the terms of the Creative Commons Attribution 4.0 International license.

\begin{abstract}
Introduction: To date, no specific therapeutic drug has been approved to target SARS-CoV-2. Hence, it remains a major challenge to decide what potential therapeutic regimens to treat COVID-19 patients. This study aims to investigate curcumin and virgin coconut oil (VCO) effects on cytokine levels (IL-1 $\beta$, IL-2, IL-6, IL-18, TNF- $\alpha$, and IFN- $\beta$ ) in COVID-19 patients. Methods: This study was a single-center, controlled trial with a parallel Arm or a Randomized Clinical trial design. A total of sixty COVID-19 patients admitted to the Universitas Sebelas Maret Hospital, Surakarta, Indonesia, were divided into two groups. The first group, consisting of 30 patients, was treated with Azithromycin $500 \mathrm{mg}+$ Oseltamivir $2 \times 75 \mathrm{mg}$ + Hydroxychloroquine $400 \mathrm{mg} /$ day for 5 days. The second group, comprising 30 patients, was treated with Azithromycin $500 \mathrm{mg}+$ Oseltamivir $2 \times 75 \mathrm{mg}+$ Hydroxychloroquine $400 \mathrm{mg} /$ day for 5 days, added with VCO $30 \mathrm{~mL}$ and curcumin $3 \times 1 \mathrm{~g} /$ day for 21 days. The cytokine profiles of the serum samples were analyzed by the enzyme-linked immunosorbent assay (ELISA) on days 1, 14, and 21. Results: Our study showed that the second group had a significant reduction in IL-1 $\beta$, IL-2, IL-6, TNF- $\alpha$, and IFN- $\beta$ levels after being treated with standard therapy added with curcumin and VCO on day $21(p<0.05)$. Conclusion: These results suggested that curcumin and VCO might benefit the treatment of COVID-19 patients. Key words: COVID-19, Curcumin, Cytokines, Virgin coconut oil.
\end{abstract}

\section{INTRODUCTION}

Coronavirus Disease 2019 (COVID-19) is a respiratory disease reported to have emerged in late December 2019 in Wuhan, China. It causes by a novel coronavirus known as Severe Acute Respiratory Syndrome Coronavirus-2 (SARSCoV-2). COVID-19 has grown rapidly and was declared a pandemic by WHO. ${ }^{1}$ In patients with severe MERS, serum cytokine and chemokine levels are significantly higher than those in patients with mild to moderate MERS. An increase of many pro-inflammatory cytokines was reported, including IL-1, IL-2, IL-4, IL-6, IL-8, IL-10, IL-12, IL-17A, TNF- $\alpha$, and GM-CSF. These conditions are known as cytokine storms. The SARS-CoV-2 virus causes an excessive inflammatory reaction. Several studies analyzing cytokine profiles of COVID-19 patients suggested that the cytokine storm directly correlated with lung injury, multi-organ failure, and unfavorable prognosis of severe COVID-19. ${ }^{2}$ Thus, elevated levels of pro-inflammatory cytokines indicate the immune response against viral replication and viral shedding. Besides, IFN $\beta-1 \mathrm{a}$ has direct in vitro antiviral activity against SARSCoV-2. In contrast, IFN-1 $\beta$ has been identified as the key therapeutic cytokine in shortening the time to negative conversion of SARS-CoV-2 nasopharyngeal swabs in a recent trial. ${ }^{3}$

To date, no specific drug has been approved to treat COVID-19 patients, but preventive and supportive therapies have been done to decrease more serious illnesses. Many natural agents have received attention due to their potential anti-inflammatory, antiviral, and antioxidant properties. These products are collectively named nutraceuticals. Curcumin has pharmacological properties, especially as an anti-inflammatory agent. Thus, it has a potential candidate in the therapeutic regimen. COVID-19 has various pathophysiological consequences, including pulmonary damage, elevated inflammatory response, coagulopathy, and multi-organ damage. ${ }^{4}$ Studies reveal the potential benefits of curcumin against respiratory viral infections..$^{5-7}$ A recent in silico study reported a stable interaction between curcumin and SARS-CoV-2 enzymes. ${ }^{8}$

In addition, virgin coconut oil (VCO), a coldprocessed form of coconut oil, is traditionally consumed in Asian countries owing to its nutritional and medicinal properties. VCO is wetprocessed, which results in the retention of bioactive components, including tocopherols, tocotrienols, and polyphenols. These bioactive compounds may have been responsible for anti-inflammatory properties. Monolaurin, a glycerol and lauric acid product, modulates the inflammatory process and possesses immunomodulatory and antimicrobial properties. ${ }^{9}$ VCO and its derivatives are safe and effective antiviral compounds in humans and animals. In addition, coconut oil itself has been shown to have anti-HIV properties in small clinical studies. ${ }^{10}$ Despite the documented evidence, VCO's medicinal properties in mediating the health benefits have not been explored.

This study hypothesized that curcumin and VCO interfered in the crucial steps of the pathophysiology of COVID-19 and proposed a potential role in

Cite this article: Hartono, Suryawati B, Sari Y, Novika RGH, Avicena A, Maryani, et al. The Effect of Curcumin and Virgin Coconut Oil Towards Cytokines Levels in COVID-19 Patients at Universitas Sebelas Maret Hospital, Surakarta, Indonesia. Pharmacogn J. 2022;14(1): $216-225$. 
inflammatory responses for COVID-19 patients, especially IL-1 $\beta$, IL-2, IL-6, IL-18, TNF- $\alpha$, and IFN- $\beta$ levels.

\section{MATERIALS AND METHODS}

\section{Trial design}

This study was a single-center, controlled trial with a parallel Arm or a Randomized Clinical trial design. The experiment protocols were approved by the ethics board of Universitas Sebelas Maret (No.066/ UN27.06.6.1/KEPK/EC/2020).

\section{Participants}

The severe acute respiratory syndrome department of Universitas Sebelas Maret Hospital screened patients with an age range of 18 to 60 years from May to September 2020 based on the following criteria:

Inclusion criteria:

New patients who were confirmed to be infected with COVID-19.

Patients with mild-moderate symptoms of COVID-19 according to criteria on the Decree of the Minister of Health of the Republic of Indonesia number HK.01.07/Menkes/5671/2021 concerning the clinical management of coronavirus disease 2019 (Covid-19) in the health service facility.

Signing informed consent.

The exclusion criteria of this study were included as follow:

Severe and critical pneumonia due to COVID-19.

Patients with elevated ALT/AST of $>6 \mathrm{x}$ the upper limit of normal values (ALT 7-56 UI, AST 10-40 UI).

Patients with elevated levels of urea and creatinine (normal urea level: $10-44 \mathrm{mg} / \mathrm{dL}$ and normal creatinine level: $0.6-1.4 \mathrm{mg} / \mathrm{dL}$ ).

Patients with a history of comorbidity.

Patients who were pregnant or breastfeeding.

Patients who were received herbal or supplement treatment.

Patients who taken a drug regimen for COVID-19.

Patients who had allergies.

Patients who complain of side effects that, according to the doctor's consideration, the addition of curcumin + VCO must be discontinued.

\section{Sampling technique}

This study utilized a randomized controlled trial. The replication was determined according to the replication formula for experimental research with a completely randomized design.

$(\mathrm{t}-1)(\mathrm{r}-1)>15$

$(2-1)(\mathrm{r}-1)>15$

$1+r>15$

$\mathrm{r}>14$

Note:

$\mathrm{t}=$ amount of intervention group

$r=$ replication amount of intervention group

Therefore, the minimal number of samples based on the calculation was 14 in each group. A total of 15 patients with mild COVID-19 and 15 with moderate COVID-19 were included in the control group. In addition, 7 mild COVID-19 patients and 23 moderate COVID-19 patients were appointed as respondents in this study.

\section{Intervention and comparator}

Control group (Grup I): Thirty patients were diagnosed with SARSCoV-2 infection and treated with Azithromycin $500 \mathrm{mg}+$ Oseltamivir 2x75 mg + Hydroxychloroquine $400 \mathrm{mg}$ /day for 5 days.

Experimental group (Grup II): Thirty patients were diagnosed with SARS-CoV-2 infection and treated with Azithromycin $500 \mathrm{mg}+$ Oseltamivir 2x75 mg + Hydroxychloroquine $400 \mathrm{mg} /$ day for 5 days, added with VCO $30 \mathrm{ml}$ and curcumin $3 \mathrm{x} 1 \mathrm{~g} /$ day for 21 days. Due to its proteolytic action, VCO is directly absorbed when administrated orally. It also substantially promotes the absorption of curcumin, enhances its bioavailability, and makes a perfect combination. ${ }^{11}$

\section{Herbal ingredients}

\section{Curcumin}

The curcumin preparation was obtained from local Indonesian products registered with the Food and Drug Administration of the Republic of Indonesia, with a dose referring to previous studies, namely $3,000 \mathrm{mg} /$ day. This dose has been approved to reduce infection and produce an immunomodulatory effect in cases of recurrent respiratory tract infections. ${ }^{12}$

\section{Virgin Coconut Oil (VCO)}

The VCO was obtained from local agricultural products companies and produced with no preservatives or additives using the freeze-thaw method. The selected VCO products are those registered with the Food and Drug Administration of the Republic of Indonesia. According to previous studies, the dose was set at $30 \mathrm{~mL}$ per day in adult. ${ }^{13}$

\section{PCR swab examination}

PCR swabs were conducted to determine clinical improvement after treatment. Nasopharyngeal and oropharyngeal swabs were performed on days 1, 10, 14, and 21 at the Universitas Sebelas Maret Hospital, Surakarta, Indonesia. RNA extraction was conducted utilizing L9iferiver Novel Coronavirus (2019-nCoV) RNA Isolation Kit (for Auto-Extraction) (Liferiver ME-0012, Shanghai ZJ Bio-Tech) following the manufacturer instruction.

Real-Time RT-PCR tests were performed on throat swab specimens at the Universitas Sebelas Maret Hospital, Indonesia, utilizing Novel Coronavirus (2019-nCoV) Real-Time Multiplex RT-PCR Kit (Detection of 3 Genes). SARS-CoV-2 open reading frame $1 \mathrm{ab}$ (ORF1ab), N, and $\mathrm{E}$ gene fragments were amplified, and the conditions for amplification were $45^{\circ} \mathrm{C}$ for $10 \mathrm{~min}$ and $95^{\circ} \mathrm{C}$ for $3 \mathrm{~min}$, followed by 45 cycles of $95^{\circ} \mathrm{C}$ for $15 \mathrm{~s}$ and $58^{\circ} \mathrm{C}$ for $30 \mathrm{~s}$. When both targets (ORF1ab, gene $\mathrm{N}$, and gene E) were tested positive by specific real-time RT-PCR, the case was considered laboratory-confirmed. A cycle threshold value (CT value) less than 37 was defined as positive, and a CT value more than 41 was defined as negative. A medium load, defined as a CT value ranging from 37 to 40 , required confirmation by retesting.

\section{Cytokine assay}

The cytokine levels in serum were measured utilizing Enzyme-Linked Immunosorbent Assay (ELISA). The kits of IL-1 $\beta$, IL-2, IL-6, IL-18, IFN- $\beta$, and TNF- $\alpha$ (R\&D Systems Bio-Techno) were used according to the manufacturer's instructions. Plates were developed using tetramethylbenzidine substrate (Thermo Fisher Scientific), stopped using $2 \mathrm{~N} \mathrm{HCL}$, and read at a dual-wavelength of $450 \mathrm{~nm}$ in a microplate reader (Bio-Rad) to obtain the optical density (OD) and concentration values.

\section{Statistical analysis}

All statistical analyses were performed using SPSS version 16.0 (SPSS Inc.). The normality test used the Independent-group t-tests, while 
the homogeneity test used the Levene test. Different tests used the Friedman test and continued with the post hoc test. All data was displayed with mean \pm standard deviation (SD). All statistical analyses used a significant level $(p<0.05)$.

\section{RESULTS}

\section{Patient's characteristics}

Table 2 is presented the percentages of respondents in the control and experimental groups. Sixty respondents were male (56.67\%) with an age range of 36 to 49 years and a body mass index range of 18.5 to 24.9. In the control group, 15 (25\%) respondents had both mild and moderate COVID-19, while in the experimental group, 23 (38.33\%) respondents had moderate COVID-19. No respondent had comorbidities such as heart attack, hypertension, or diabetes. No respondent needed assistance to do their daily activities and receive advanced respiratory support. No respondent experienced side effects after the intervention. Regarding the patient characteristic, there were no significant differences in age, gender, BMI, comorbidities, assistance, advanced respiratory support, and side effects experienced by the respondents in the control and experimental groups $(\mathrm{p}>0.05)$. In contrast, respondents with Severe COVID-19 in the control and experimental groups indicated significant differences with a p-value $<0.05$.

\section{Patients recovery time}

As shown in Figure 1, the recovery time of COVID-19 patients treated with standard treatment, curcumin, and VCO was faster than COVID-19 patients who were only treated with standard treatment. A total of $54 \%$ of respondents had negative PCR results on day 10 and $0 \%$ in more than 21 days in the group with standard treatment + curcumin + VCO supplementation (Group II). A total of $50 \%$ of the respondents had negative PCR results at day 21 in the group with only standard treatment (group I).

\section{Cytokines levels}

We also evaluated the levels of IL-1 $\beta$, IL-2, IL-6, IL-18, TNF- $\alpha$, and IFN- $\beta$ in serum samples from the first and second groups of
COVID-19 patients on days 1, 14, and 21. As presented in Figure 2, the first group treated with Azithromycin $500 \mathrm{mg}+$ Oseltamivir $2 \times 75$ $\mathrm{mg}+$ Hydroxychloroquine $400 \mathrm{mg} /$ day for 5 days had no significant reduction in the levels of IL- $1 \beta$, IL- 6 , IL-18, TNF-a, and IFN- $\beta$ on days 1,14 , and $21(p<0.05)$. Meanwhile, the second group treated with Azithromycin $500 \mathrm{mg}+$ Oseltamivir $2 \times 75 \mathrm{mg}+$ Hydroxychloroquine $400 \mathrm{mg}$ /day for 5 days, added with $3 \mathrm{~g}$ of curcumin and $30 \mathrm{~mL}$ of VCO for 21 days, had a significant reduction in the levels of IL-1 $\beta$, IL-2, IL-6, IL-18, and IFN- $\beta$ after 21 days ( $<<0.05)$. These findings demonstrated that curcumin and VCO inhibited IL-1 $\beta$, IL-2, IL-6, IL-18, and IFN- $\beta$ levels.

\section{DISCUSSION}

The COVID-19 outbreak has been declared a pandemic by WHO, with a crude mortality rate of about $2.3 \%$. The pathogenesis of COVID-19 involves a potent inflammatory response. The host immune response is the first-line defense triggered by the viral infection, which will induce cell death and cytopathic. ${ }^{14}$ Pro-inflammatory cytokines play an important role in the immune reaction during the viral infection and can be utilized to predict the severity of the clinical outcomes. ${ }^{15,16}$ Evidence proved that close interaction between virus SARS-CoV-2 and the immune system resulted in diverse clinical manifestations ${ }^{17}$ and activated inflammasome. The inflammasome is reflected by cytokine storms in COVID-19 patients that may worsen the disease. ${ }^{18}$ The cytokines storms of clinical findings contribute to the pro-inflammatory cytokines secretion such as IL-1, IL-6, IL-18, IFN- $\alpha$, and TNF- $\alpha{ }^{19}$ Besides, the major causes of Acute Respiratory Distress Syndrome (ARDS) and multiple organ failure found in critically ill COVID-19 patients..$^{20}$ According to Tanaka et al. (2021), IL-1 $\beta$ is a potent inducer of COX2 expression. IL-2 is a pleiotropic cytokine that dissects the signaling pathways, controlling both pro and anti-inflammatory differentiation and homeostasis. IL-6 is a pro-inflammatory cytokine that plays a key role in the host defense mechanism. IL-18 is a cytokine that stimulates Th1 immune responses, which play a crucial role in the host defense against intracellular microbes through induction of IFN- $\alpha$. IFN- $\beta$ is an immunomodulator that decreases inflammation and prevents damage. Lastly, TNF- $\alpha$ is a pleiotropic cytokine that regulates many facets of macrophage function. ${ }^{21}$

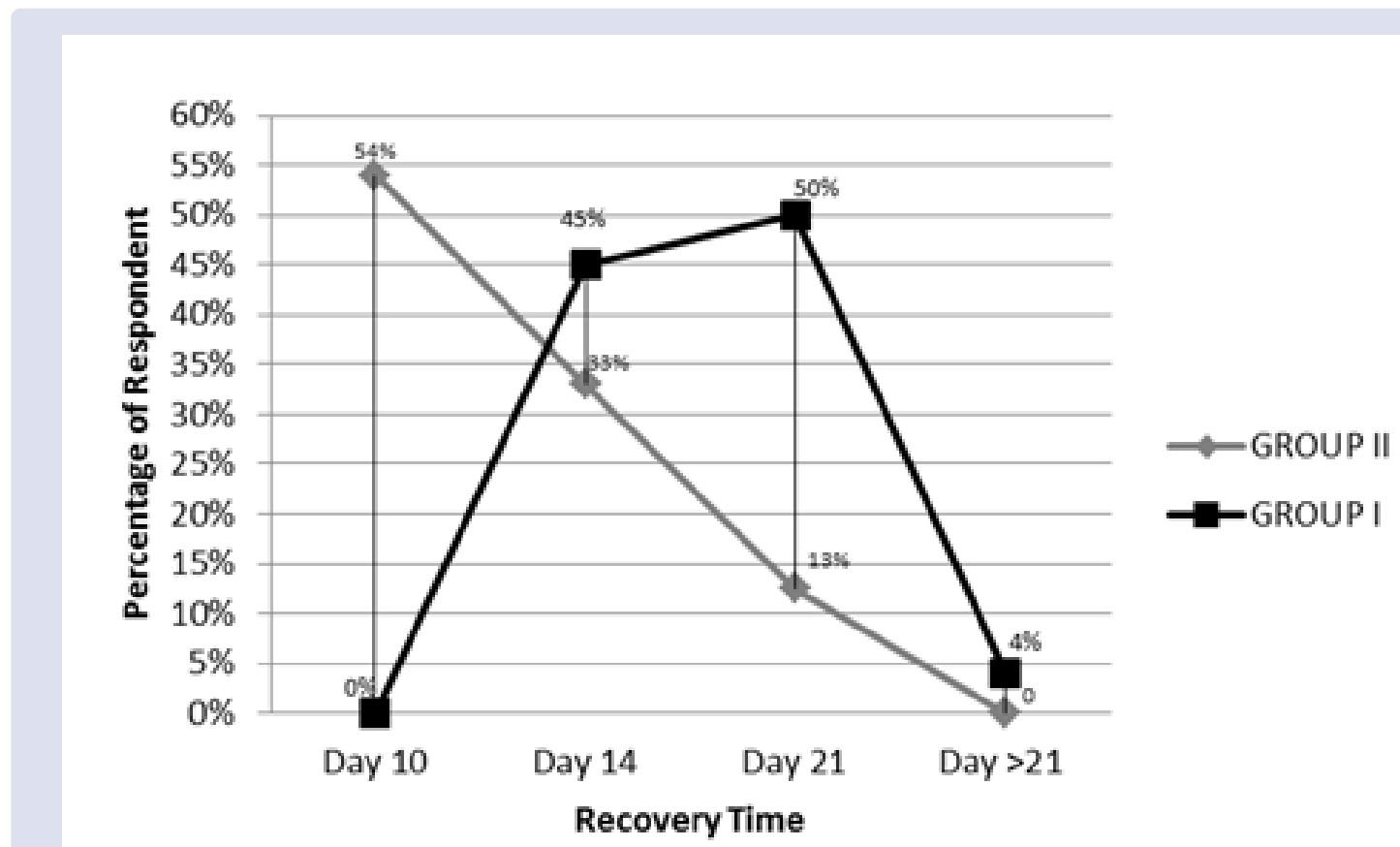

Figure 1: Conversion to negative PCR results of the first (black) and second (grey) groups. 

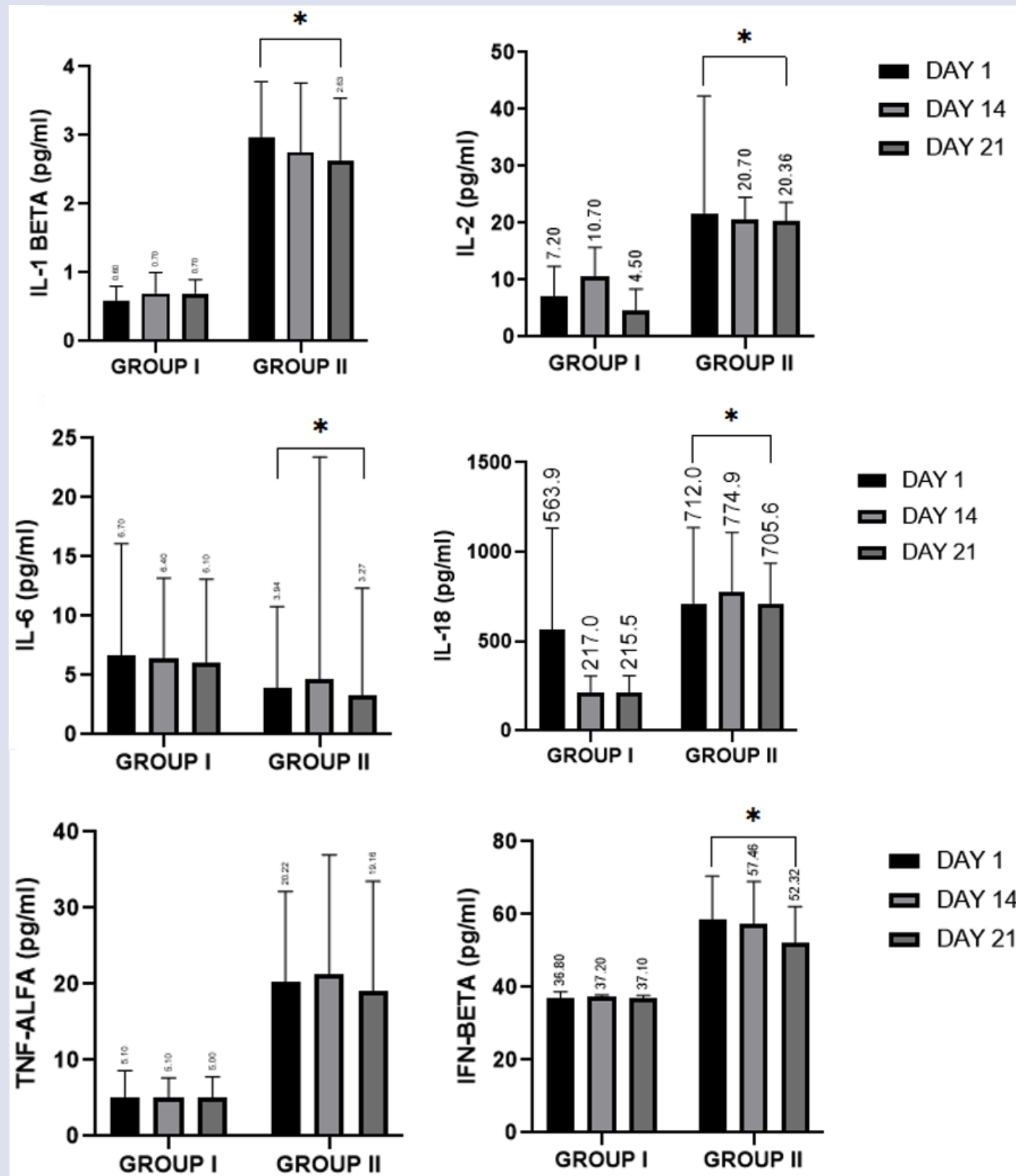

Figure 2: Cytokine levels on days 1, 14, and 21 in COVID-19 patients. Group one was treated with Azithromycin + Oseltamivir + Hydroxychloroquine (standard treatment). Group 2 was treated with standard treatment, VCO and curcumin.

Peter et al. reported that the synergetic effect of antiviral treatment was combined with appropriate anti-inflammatory treatment. ${ }^{22}$ This study demonstrated the first-time effect of VCO and curcumin supplementation (anti-inflammatory treatment) on mild and moderate COVID-19 patients. As shown in Figure 1, the recovery time of COVID-19 patients treated with standard treatment, curcumin, and VCO was faster than those treated only with standard treatment without curcumin and VCO. Figure 2 illustrates that almost all cytokines, including IL- $1 \beta$, IL-2, IL-6, IL-18, TNF- $\alpha$, and IFN- $\beta$, in the control group had no significant difference. In contrast, the treatment group showed a significant reduction in the IL-1 $\beta$, IL-2, IL-6, IL-18, and IFN- $\beta$ levels after 21 days. This study demonstrated that standard treatment + curcumin + VCO mediate its anti-inflammatory activity by reducing the secretion of IL- $1 \beta$, IL- 2 , IL-6, IL-18, and IFN- $\beta$. Previous studies revealed that in vitro, in vivo, and based on clinical trials, curcumin plays an important role as an anti-inflammatory and antiviral against various viruses, bacteria, and fungi. ${ }^{24}$
Curcumin was first isolated by Vogel and Pelletier in 1815 from the rhizomes of $C$. longa. ${ }^{25}$ Its anti-inflammatory activity increases the expression of T-regulatory cells, decreases pro-inflammatory cytokines in the adaptive immune system, and hence helps produce anti-inflammatory cytokines. Pro-inflammatory cytokines inhibited by curcumin include IL-1, IL-2, IL-6, IL-8, IL-12, TNF- $\alpha$, monocyte chemoattractant protein, and migration inhibitory protein resulting from downregulation of the inflammatory response..$^{26} \mathrm{~A}$ recent report by Lin et al. indicated that long-term infection with SARS-CoV-2 may increase IL-6, TNF- $\alpha$, IFN- $\gamma$, IL-2, IL-4, and IL-10 cytokines. ${ }^{27}$

In addition, pro-inflammatory cytokines play crucial role in the immune response against viral replication and viral shedding. Curcumin showed the best inhibitory effect on viral replication. Previous studies reported that curcumin could inhibit hepatitis $C$ virus subgenomic RNA replication. ${ }^{24}$ It also revealed that curcumin could block the entry step of the viral life cycle. ${ }^{28}$ Recent evidence from in 
Table 1: Symptom degree and clinical symptom according to the criteria of the Minister of Health of the Republic of Indonesia.

\begin{tabular}{ll}
\hline Symptom degree & Clinical symptoms \\
Asymptomatic & No complaints and clinical symptoms \\
& $\begin{array}{l}\text { Patients with symptoms without evidence of viral pneumonia or hypoxia. The appearing symptoms include fever, } \\
\text { cough, fatigue, anorexia, shortness of breath, }\end{array}$ \\
& Myalgia. Other non-specific symptoms, including sore throat, nasal congestion, headache, diarrhea, nausea and \\
Mild & vomiting, loss of smell (anosmia), or loss of taste (ageusia) that occur before the onset of respiratory symptoms, are \\
& also frequently reported. History and physical examination. Oxygenation status: SpO2 $>95 \%$ with room air.
\end{tabular}

Table 2: Patient's characteristics.

\begin{tabular}{|c|c|c|c|c|}
\hline Characteristic & All patients $(n=60)$ & Control Group $(n=30)$ & $\begin{array}{l}\text { Experimental Group } \\
\qquad(n=30)\end{array}$ & $p$-value \\
\hline \multicolumn{5}{|l|}{ Age (years) ${ }^{a}$} \\
\hline $18-35$ & $25(41.67)$ & $11(18.33)$ & $14(23.33)$ & \multirow{3}{*}{$0.114^{\mathrm{b}}$} \\
\hline $36-49$ & $15(25.00)$ & $5(8.33)$ & $10(16.67)$ & \\
\hline $50-60$ & $20(33.33)$ & $14(23.33)$ & $6(10.00)$ & \\
\hline \multicolumn{5}{|l|}{ Gender ${ }^{\mathrm{a}}$} \\
\hline Male & $34(56.67)$ & $16(26.67)$ & $18(30.00)$ & \multirow[t]{2}{*}{$0.606^{\mathrm{b}}$} \\
\hline Female & $26(43.33)$ & $14(23.33)$ & $12(20.00)$ & \\
\hline \multicolumn{5}{|c|}{ Body Mass Index a } \\
\hline$<18.5$ & $6(10.00)$ & $2(3.33)$ & $4(6.67)$ & \multirow{4}{*}{$0.765^{\mathrm{b}}$} \\
\hline $18.5-24.9$ & $43(71.67)$ & $24(40.00)$ & $19(31.67)$ & \\
\hline $25-29.9$ & $11(18.33)$ & $4(6.67)$ & $7(11.67)$ & \\
\hline$>30$ & $0(0.00)$ & $0(0.00)$ & $0(0.00)$ & \\
\hline \multicolumn{5}{|c|}{ COVID-19 severities ${ }^{\text {a }}$} \\
\hline Mild & $22(36.67)$ & $15(25.00)$ & $7(11.67)$ & \multirow{3}{*}{$0.034^{\mathrm{b}^{*}}$} \\
\hline Moderate & $38(63.33)$ & $15(25.00)$ & $23(38.33)$ & \\
\hline Severe & $0(0.00)$ & $0(0.00)$ & $0(0.00)$ & \\
\hline \multicolumn{5}{|c|}{ Having Comorbidities ${ }^{\mathrm{a}}$} \\
\hline Yes & $0(0.00)$ & $0(0.00)$ & $0(0.00)$ & \multirow[t]{2}{*}{-} \\
\hline No & $60(0.00)$ & $30(50.00)$ & $30(50.00)$ & \\
\hline \multicolumn{5}{|c|}{$\begin{array}{l}\text { Assistance required to do daily } \\
\text { activities }\end{array}$} \\
\hline Yes & $0(0.00)$ & $(0.00)$ & $(0.00)$ & \multirow{2}{*}{$1^{\mathrm{b}}$} \\
\hline No & $60(100.00)$ & $30(50.00)$ & $30(50.00)$ & \\
\hline \multicolumn{5}{|c|}{$\begin{array}{l}\text { Receiving advance respiratory } \\
\text { support }^{\mathrm{a}}\end{array}$} \\
\hline Yes & $0(0.00)$ & $(0.00)$ & $(0.00)$ & \multirow{2}{*}{$1^{\mathrm{b}}$} \\
\hline No & $60(100.00)$ & $30(50.00)$ & $30(50.00)$ & \\
\hline Side Effects & $1(0.00)$ & $(0.00)$ & $(0.00)$ & \multirow{2}{*}{$1^{\mathrm{b}}$} \\
\hline Yes & $60(100.00)$ & $30(50.00)$ & $30(50.00)$ & \\
\hline
\end{tabular}

silico studies demonstrated that curcumin could prevent SARS-CoV-2 entry into cells by blocking the viral binding sites and the cell ligands (spike protein and ACE-2 receptors), downregulating transmembrane serine protease 2 (TMPRSS-2), and interfering with viral replication through the interaction with various viral proteins. Hydroxyl group at the meta-position of the benzene ring and the double bonds in the central seven-carbon chain in the curcumin derivatives may be essential for neuraminidase inhibitory activity. ${ }^{29}$ Curcumin acts as a direct antiviral and protects the host by inhibiting TLR4 and other TLRs signaling. ${ }^{30}$

Studies indicated the potential benefits of curcumin against respiratory viral infections. ${ }^{7}$ Curcumin can effectively inhibit the viral enzymes of SARS-coronavirus. Recent in-silico predictions suggested a stable interaction between curcumin and SARS-CoV-2 enzymes. ${ }^{8}$ Regulations of coronavirus-infection-associated responses by curcumin are considered. Moreover, curcumin has been proved to modulate various pathophysiology consequences of SARS-CoV-2 infection. The entry of SARS-CoV-2 into host cells is also predicted to be inhibited by curcumin through direct interaction with viral ligands or target cell receptors. The inhibition of transmembrane serine protease 2 (TMPRSS2) by curcumin has been reported, a priming enzyme for SARS-CoV-2 cellular entry. The inhibitory effect of curcumin against coronavirus and other respiratory-associated viral infections demonstrates its promising potential against COVID-19., ${ }^{4}$ Moreover, curcumin inhibits caspase 1 activation and IL- $1 \beta$ secretion 


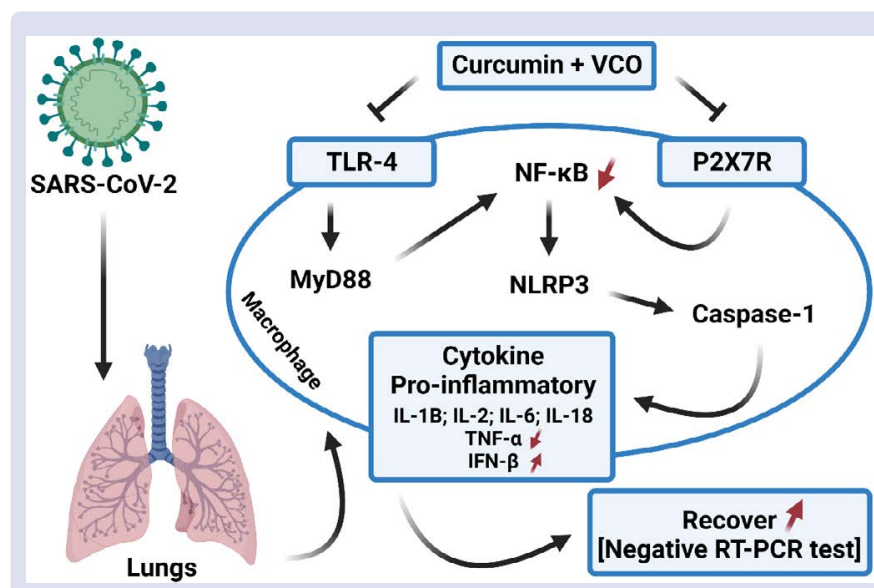

Figure 3: Novelty and schematic representation of curcumin and VCO supplementation affecting pro-inflammatory cytokines in COVID-19 patients. This figure was created in BioRender.

by suppressing both LPS priming and inflammasome activation. The NLRP3 inflammasome can be activated in TLR agonist by inducing the NLRP3 and pro-IL- $1 \beta$ synthesis via the NF-kB pathway. ${ }^{31}$

Virgin coconut oil (VCO) has been consumed worldwide for various health-related reasons that have been scientifically evaluated. VCO is also effective against treating chronic inflammation in arthritis, which could be due to its anti-inflammatory properties and ability to overcome nitric oxide-induced oxidative damage. ${ }^{32} \mathrm{VCO}$ has been reported to contain polyphenols. ${ }^{33}$ Antioxidants can scavenge a wide range of ROS. The high number of hydroxyl groups impacts on several antioxidant activities ${ }^{34}$ and neutralizes free radicals. ${ }^{26}$ The molecular mechanism of polyphenol anti-inflammatory activities includes inhibiting enzymes associated with pro-inflammatory properties such as COX-LOX and iNOS, inhibiting NF-kB, and activating protein-1 related factors. ${ }^{35}$ The polyphenols in VCO could combat MTX-induced oxidative stress. Oxidative stress has been implicated in commencing or amplifying inflammation by activating several transcription factors associated with inflammatory mechanisms.

We described the mechanism of curcumin and VCO against proinflammatory cytokines levels in COVID-19 patients (Figure 3). COVID-19 leads to a critical clinical condition with high inflammation and excessive viral replication. Clinical observation in COVID-19 patients indicates that the infection promotes immune deregulation characterized by a high level of pro-inflammatory cytokines. Many studies revealed that flavonoids possess significant anti-inflammatory properties in vitro and in vivo. ${ }^{23} \mathrm{We}$ assumed that the polyphenols in curcumin and VCO act as antioxidants that may induce antiinflammatory, antiviral, and antioxidant effects in COVID-19 patients. Curcumin and VCO are expected to have a therapeutic effect by inhibiting the NF-kB signaling pathway. In addition, curcumin and VCO can regulate various pro-inflammatory cytokines by inhibiting the expression of TLR-4, which leads to downregulation of NF-kB.

Toll-like receptor 4 (TLR-4) is expressed on the plasma membrane of immune cells that plays an important role in the inflammatory process. $^{36}$ In the TLR-4 signaling pathway, the MyD88-dependent signaling pathway is an important activator of NF-B and the subsequent regulatory effect of NF- $\kappa \mathrm{B}$ signaling. ${ }^{37}$ Inhibition of Nf$\mathrm{k} \beta$ signaling reduces NLRP3 inflammasome activation. Beta-HBmediated inhibition of NLRP3 inflammasome activation is possible by limiting $\mathrm{K}+$ efflux pro-ATP $M$ cell and reducing IL- $1 \beta$ and IL-18 without significantly affecting TNF- $\alpha$ level. ${ }^{38}$
In addition to inhibiting NF- $\mathrm{k} \beta$ signaling through TLR-4, curcumin and VCO are assumed to inhibit purinergic $2 \mathrm{X} 7$ receptors (P2X7R). $\mathrm{P} 2 \mathrm{X} 7 \mathrm{R}$ is a member of the P2X subfamily, which plays an important role in macrophages, regulates cytokine production, and is activated by extracellular ATP to induce NLRP3 inflammasome assembly. ${ }^{39}$ P2X7R decreases the phosphorylation level of the p65 subunit of NFkB, but not the TLR4 or MyD88 pathway. Then, the decrease in P2X7R expression with TLR4-MyD88-NF- $\kappa \mathrm{B}$ signaling regulates NLRP3 expression, caspase-1 activation. Therefore, these conditions are expected to decrease in storm cytokines or pro-inflammatory protein expression. However, another study suggested that curcumin may reduce the production TNF- $\alpha$. In this regard, curcumin inhibits the ROS by increasing glutathione (GSH) activity as well as modulating several signaling pathways such as PPAR $\gamma$, JNK, NF-kB and Nrf2. ${ }^{40}$ These decreasing inflammatory cytokines fasten the recovery time of COVID-19 patients supplemented by curcumin and VCO.

Our study highlighted the potential role of curcumin and VCO supplementation in COVID-19 patients. Therefore, it was proposed that curcumin and VCO can be used to treat COVID-19 patients.

\section{CONCLUSION}

Curcumin and VCO reduced the IL-1 $\beta$, IL-2, IL-6, IL-18, and IFN- $\beta$ levels in COVID-19 patients after being treated for 21 days. Curcumin combined with VCO could be a nutraceutical resources for the recovery of COVID-19 patients.

\section{DISCLOSURE STATEMENT}

The authors have no conflicts of interest to declare.

\section{ACKNOWLEDGMENTS}

This work was supported in part by a grant from RISTEK-BRIN (Grant Number: 74/F1/PKS-KCOVID-19.D/VI/2020) and LPDP (Grant Number: 113.1/UN27.21/HK/2020).

\section{AUTHOR CONTRIBUTION}

H, B.S, and G.H.N developed the concept and design of this study; A.A, Y.S, M, C.S, L.S, and H.A collected the samples and provided clinical parameters; H, B.S, N.J.W, N.Y.R, A.N.M.A wrote the manuscript; H, R.G.H.N, and L.S conducted experiment and analyzed the data. All authors reviewed the results and approved the final version of the manuscript.

\section{REFERENCES}

1. Ansori ANM, Kharisma VD, Muttaqin SS, Antonius Y, Parikesit AA. Genetic variant of SARS-CoV-2 isolates in Indonesia: Spike glycoprotein gene. J Pure Appl Microbiol. 2020;14:971-978.

2. Ragab D, Salah Eldin H, Taeimah M, Khattab R, Salem R. The COVID-19 cytokine storm; what we know so far. Front Immunol. 2020;11:1446.

3. Bosi E, Bosi C, Rovere Querini P, Mancini N, Calori G, Ruggeri A, etal Interferon $\beta-1$ a (IFN $\beta-1 a$ ) in COVID-19 patients (INTERCOP): Study protocol for a randomized controlled trial. Trials. 2020;21(1):939.

4. Soni VK, Mehta A, Ratre YK, Tiwari AK, Amit A, et al. Curcumin, a traditional spice component, can hold the promise against COVID-19? Eur J Pharmacol. 2020;886:173551.

5. Avasarala S, Zhang F, Liu G, Wang R, London SD, London L. Curcumin modulates the inflammatory response and inhibits subsequent fibrosis in a mouse model of viral-induced acute respiratory distress syndrome. PLoS One. 2013;8(2):e57285.

6. Barnard DL, Kumaki Y. Recent developments in anti-severe acute respiratory syndrome coronavirus chemotherapy. Future Virol. $2011 ; 6(5): 615-631$ 
7. Xu Y, Liu L. Curcumin alleviates macrophage activation and lung inflammation induced by influenza virus infection through inhibiting the NF-KB signaling pathway. Influenza Other Respir Viruses. 2017; 11(5):457-463

8. Kharisma VD, Agatha A, Ansori ANM, Widyananda MH, Rizky WC, Dings TGA, et al. Herbal combination from Moringa oleifera Lam. and Curcuma longa L. as SARS-CoV-2 antiviral via dual inhibitor pathway: A viroinformatics approach. J Pharm Pharmacogn Res. 2022; 10(1):138-146.

9. Hima L, Pratap UP, Karrunanithi S, Ravichandran KA, Vasantharekha $\mathrm{R}$, ThyagaRajan S. Virgin coconut oil supplementation in diet modulates immunity mediated through survival signaling pathways in rats. J Complement Integr Med. 2019;17.

10. Zentek J, Buchheit-Renko S, Ferrara F, Vahjen W, Van Kessel $A G$, Pieper R. Nutritional and physiological role of medium-chain triglycerides and medium-chain fatty acids in piglets. Anim Health Res Rev. 2011;12(1):83-93.

11. Ben Khedir S, Mzid M, Bardaa S, Moalla D, Sahnoun Z, Rebai T. In vivo evaluation of the anti-inflammatory effect of Pistacia lentiscus fruit oil and its effects on oxidative stress. Evid Based Complement Alternat Med. 2016;6108203.

12. Zuccotti GV, Trabattoni D, Morelli M, Borgonovo S, Schneider $\mathrm{L}$, Clerici M. Immune modulation by lactoferrin and curcumin in children with recurrent respiratory infections. J Biol Regul Homeost Agents. 2009;23(2):119-23.

13. Liau MK, Lee YY, Chen CK, Rassol AH. An open-label pilot study to assess the efficacy safety of VCO in reducing visceral adiposity. ISRN Pharmacol. 2011;949686.

14. Danthi P. Viruses and the diversity of cell death. Annu Rev Virol. 2016;3(1):533-553

15. Channappanavar R, Perlman S. Pathogenic human coronavirus infections: causes and consequences of cytokine storm and immunopathology. Semin Immunopathol. 2017;39(5):529-539.

16. Wong CK, Lam CW, Wu AK, Ip WK, Lee NL, Chan IH, et al. Plasma inflammatory cytokines and chemokines in severe acute respiratory syndrome. Clin Exp Immunol. 2004;136(1):95-103.

17. Dong $X, C a o Y Y, L u X X$, Zhang JJ, Du H, Yan YQ, et al. Eleven faces of coronavirus disease 2019. Allergy. 2020;75(7):1699-1709.

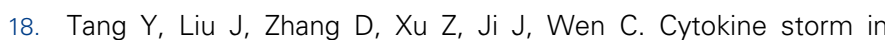
COVID-19: The current evidence and treatment strategies. Front Immunol. 2020;11:1708.

19. Ragab D, Eldin H, Taeimah, Khattab Salem R. The covid-19 cytokine storm; what we know so far. Front. immunology. 11:1446.

20. Ye Q, Wang B, Mao J. The Pathogenesis and treatment of the cytokine storm in Covid-19. Journal of infection. 2020;607-613.

21. Tanaka T, Narazaki M, Kishimoto T. IL-6 in Inflammation, immunity, and disease. Cord Spring Harbor Laboratory Press. 2021.

22. Peter et al. Calming the storm: natural immunosupressants as adjuvants to target the cytokine storm ini COVID-19. Front in pharmacology. 2020;11:583777

23. Han $\mathrm{S}, \mathrm{Xu} J$, Guo $X$, Huang M. Curcumin ameliorates severe influenza pneumonia via attenuating lung injury and regulating macrophage cytokines production. Clin Exp Pharmacol Physiol. 2018;45(1):84-93.
24. Chen MH, Lee MY, Chuang JJ, Li YZ, Ning ST, Chen JC, et al. Curcumin inhibits $\mathrm{HCV}$ replication by induction of heme oxygenase-1 and suppression of AKT. Int J Mol Med. 2012;30(5):1021-8.

25. Pivari F, Mingione A, Brasacchio C, Soldati L. Curcumin and type 2 diabetes mellitus: Prevention and treatment. Nutrients. 2019;11(8):1837.

26. Abrahams S, Haylett WL, Johnson G, Carr JA, Bardien S Antioxidant effects of curcumin in models of neuro degeneration, aging, oxidative and nitrosative stress: A review. Neuroscience. 2019;406:1-21.

27. Lin L, Luo S, Qin R, Yang M, Wang X, Yang Q, et al. Long-term infection of SARS-CoV-2 changed the body's immune status. Clin Immunol. 2020;218:108524.

28. Yedjou CG, Njiki S, Enow J, Ikome O, Latinwo L, Long R, et al. Pharmacological effects of selected medicinal plants and vitamins against COVID-19. J Food Nutr. 2021;7(2):202.

29. Lai Y, Yan Y, Liao S, Li Y, Ye Y, Liu N, et al. 3D-quantitative structureactivity relationship and antiviral effects of curcumin derivatives as potent inhibitors of influenza H1N1 neuraminidase. Arch Pharm Res. 2020;43(5):489-502.

30. Shirey KA, Blanco JCG, Vogel SN. Targeting TLR4 signaling to blunt viral-mediated acute lung injury. Front Immunol. 2021;12:705080

31. Yin $\mathrm{H}$, Guo $\mathrm{Q}$, Li X, Tang T, Li C, Wang H, et al. Curcumin suppresses IL-1 $\beta$ secretion and prevents inflammation through inhibition of the NLRP3 inflammasome. J Immunol. 2018;200(8):2835-2846.

32. Vysakh A, Ratheesh M, Rajmohanan TP, Pramod C, Premlal S, Girish kumar B, et al. Polyphenolics isolated from virgin coconut oil inhibits adjuvant induced arthritis in rats through antioxidant and anti-inflammatory action. Int Immunopharmacol. 2014;20(1):12430.

33. Intahphuak $\mathrm{S}$, Khonsung $\mathrm{P}$, Panthong A. Anti-inflammatory, analgesic, and antipyretic activities of virgin coconut oil. Pharm Biol. 2010;48(2):151-7.

34. Yeap SK, Beh BK, Ali NM, Yusof HM, Ho WY, Koh SP, et al. Anti stress and antioxidant effects of virgin coconut oil in vivo. Exp Ther Med. 2015:9(1):39-42

35. Hussain T, Tan B, Yin Y, Blachier F, Tossou MC, Rahu N. Oxidative stress and inflammation: What polyphenols can do for us? Oxid Med Cell Longev. 2016;7432797.

36. Luo $\mathrm{S}$, Zhang $\mathrm{X}, \mathrm{Xu} \mathrm{H}$. Don't overlook digestive symptoms in patients with 2019 novel coronavirus disease (COVID-19). Clin Gastroenterol Hepatol. 2020.

37. Yao $\mathrm{H}$, Sun $\mathrm{Y}$, Song $\mathrm{S}$, et al. Protective effects of dioscin against lipopolysaccharide-induced acute lung injury through inhibition of oxidative stress and inflammation. Front Pharmacol. 2017;8:120.

38. Youm YH, Nguyen KY, Grant RW, Goldberg ELM, Kim D, D'Agostino D, et al. The ketone metaboliteß-hydroxybutyrate blocks NLRP3 inflammasome-mediated inflammatory disease. Nat. Med. 2015;21:263-269.

39. Pacheo AFP, Faria XR. The potential involvment of $P 2 X 7$ receptor in COVID-19 pathogenesis: A new therapeutic target? Scand J Immunol. 2021;93;e12960.

40. Kim JS, Oh MJ, Kim SW. Activation of the Nrf2/HO-1 pathway by curcumin inhibits oxidative stress in human nasal fibroblast exposed to urban particulate matter. BMC Compl Med Ther. 2020;101. 


\section{GRAPHICAL ABSTRACT}

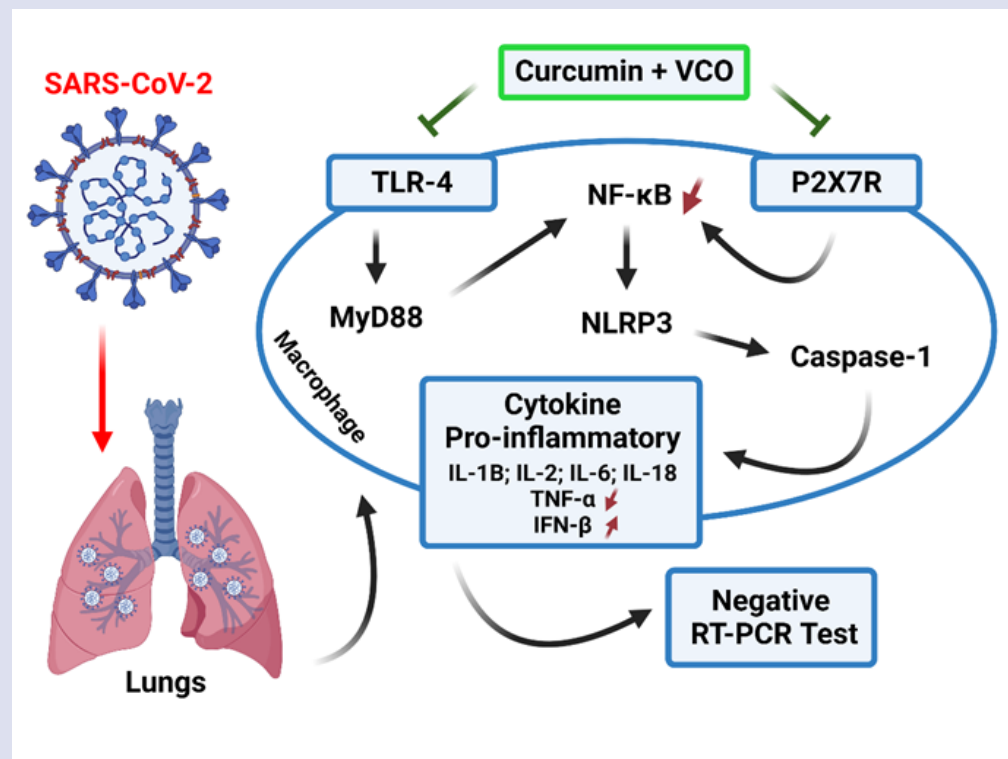

\section{ABOUT AUTHORS}

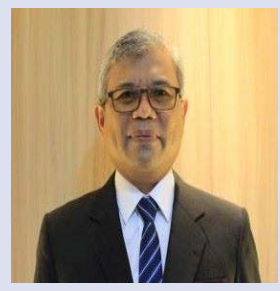

Prof. Dr. Hartono, M.Si. is a lecturer at the Faculty of Medicine Sebelas Maret University, Indonesia. Her expertise in Physiology. Hartono received a bachelor degree in Medicine in 1992 and a master degree in Environmental Science, Sebelas Maret University in 2002. In 2010, he received doctoral degree from Gajah Mada University, Indonesia. His research focuses on biology, molecular and immunologic responses caused by SARS Co-V2 infection.

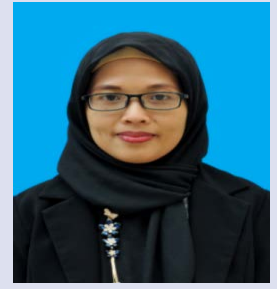

Dr. Betty Suryawati, M.Biomed.Sci., Ph.D. is a lecturer at the Faculty of Medicine Sebelas Maret University, Indonesia. Her expertise in clinical microbiology, immunology, and molecular microbiology. She received a bachelor degree in Medicine in 2001 from Gadjah Mada University, Indonesia and a master degree in Biomedical Science (M.BiomedSc) from Curtin University of Technology, Wester Australia, in 2006. Dr Suryawati received her doctoral degree (PhD) from Flinders University, South Australia in 2017. The research focuses on Antibiotic resistance bacteria, SARS-CoV 2 genomic analysis, immunologic response caused by SARSCoV2 infection, clinical and molecular microbiology.

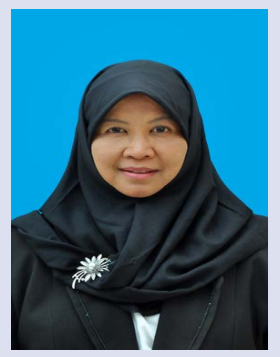

Dr. Maryani, M.Si., Sp.MK is a lecturer at the Faculty of Medicine Sebelas Maret University, Indonesia. Her expertise in clinical microbiology, disease control, and molecular microbiology. She received a bachelor degree in Medicine in 1992 from Sebelas Maret University and a master of science from Gajahmada University, Indonesia in 2002. She received her speciality in Clinical Microbiological (SpMK) from Diponegoro University, Semarang, Indonesia in 2013. The research focuses on infection prevention, antibiotic resistance bacteria, infection disease, clinical and molecular microbiology.

Dr. Revi Gama Hatta Novika, S.ST., M.Kes. is a lecturer at Faculty of Medicine, Sebelas Maret University, Indonesia and a member of the COVID-19 consortium of the Indonesian National Research and Innovation Agency (BRIN). She received her doctoral degree from the Faculty of Medicine Airlangga University, Indonesia. Her research interest is on reproductive immunology. 

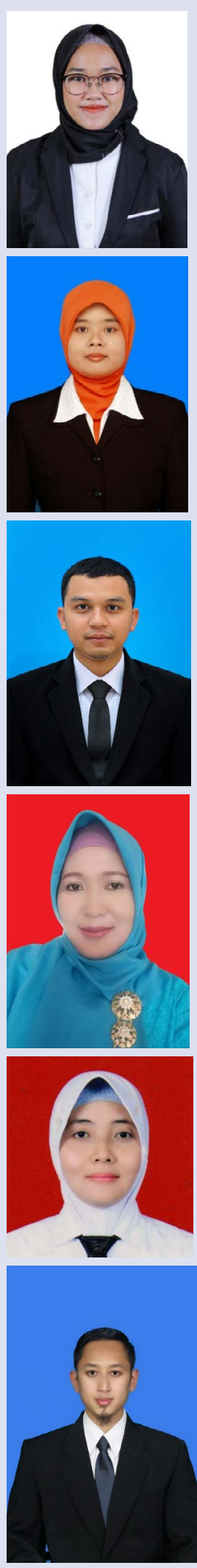

Nurul Jannatul Wahidah, S.ST., M.Kes. is lecturer of Sebelas Maret University, Indonesia. She received a master degree of reproductive health science from Airlangga University, Indonesia. Her research interest is reproductive health. She was involved in Indonesia-National Adolescent Mental Health Survey by Universitas Gadjah Mada - John Hopkins University and in Clinical trial research on the effect of ethanol extract of gendarussa capsules as male nonhormonal contraceptives.

Dr. Yulia Sari, S.Si., M.Si. is a lecturer at Faculty of Medicine, Sebelas Maret University, Indonesia. Her expertise is Parasitology and Mycology, Biotechnology, and Molecular Biology. In 2003, she received a bachelor degree in Biology and a master degree in Biotechnology (M.Si) from Gadjah Mada University, Indonesia in 2006. She received a doctoral degree from Sebelas Maret University in 2021. The research focuses on parasitology, mycology, gut microbiome, SARS-CoV2 genomic analysis, immunologic response caused by SARS-CoV2 infection, and molecular biology.

Dr. Afif Avicenna Ghufron is a lecturer at the Faculty of Medicine, Sebelas Maret University, Indonesia. He received a bachelor's degree in Medicine in 2015 and his Medical doctor certificate (MD) in 2017 from Gadjah Mada University, Indonesia.

Dr. Laily Shofiyah, M.Kes., Sp.PK is a lecturer at the Faculty of Medicine Sebelas Maret University, Indonesia. Her expertise in clinical pathology. In 2000, she received a bachelor degree and a master degree in Family medicine (M.Kes.) from Sebelas Maret University in 2015. dr. Laily also received her specialist degree in clinical pathology (Sp. PK) from Sebelas Maret University in 2015.

Dr. Hendrastutik Apriningsih is a lecturer at the Faculty of Medicine Sebelas Maret University, Indonesia. Her expertise in pulmonology and respiratory medicine. She received a bachelor degree in Medicine in 2009, a master degree in Biomedical Magister (M. Kes), and a pulmonologist from Sebelas Maret University in 2017. Currently, she is a doctoral student in medical science at Sebelas Maret University. Her research focuses on pulmonary disease and occupational lung disease.

Dr. Coana Sukmagautama, M.Kes., Sp.PD is a lecturer at the Faculty of Medicine in Sebelas Maret University, Indonesia. He is an internist and focuses on gastroenterohepatology. In 2002, he received a bachelor degree in medicine and a master of health (M.Kes) from Sebelas Maret University in 2016. He received an internal medicine degree (Sp.PD) from the Faculty of Medicine, Sebelas Maret University. In 2021, he received a fellowship on the treatment of gastrointestinal disease with basic endoscopy. His research focus is on Internal Medicine, clinical of SARS-CoV-2, and gastroenterohepatology diseases. 

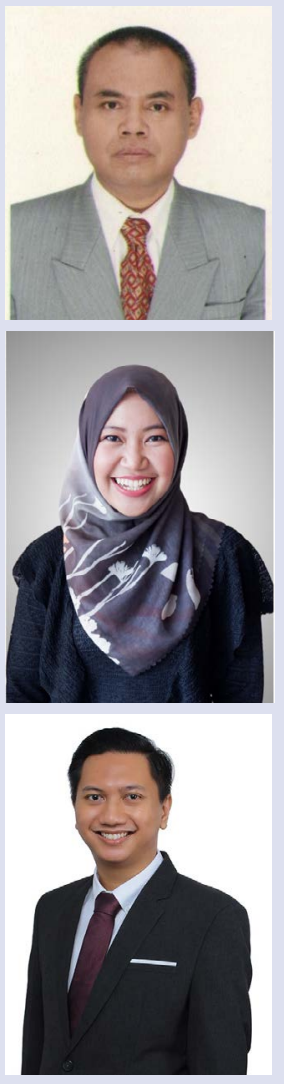

Dr. Lanjar Sumarno, M.Si. was graduated from the Faculty of Chemical Engineering, Diponegoro University, Indonesia, in 1990. He worked as a researcher at BPPT in 1992. His doctoral was received from Agricultural Industrial Technology, IPB Bogor, Indonesia. His focus research is in biotechnology, such as the isolation of fermented products as raw materials for antibiotic drugs, probiotic foods, and biopesticide fermentation. In 2020, he worked as Deputy Secretary for Innovation Strengthening, Ministry of Research and Technology.

Nanda Yuli Rahmawati, S.Si., M.Sc. is a doctoral candidate in medical sciences at the Faculty of Medicine, Universitas Airlangga, Indonesia. She completed her B.Sc. in biology at Universitas Brawijaya, Indonesia and her M.Sc. in disease mechanism at the University of Tsukuba, Japan. She worked at Tsukuba Primate Research Center (TPRC) and RIKEN BioResource Center, Japan, in 2016-2018. Her research projects are related to molecular biology, immunology, and vaccinology. Her actual research projects are the development of a biomarker for endometriosis and a peptide vaccine for COVID-19.

Arif Nur Muhammad Ansori, S.Si., M.Si. is a doctoral candidate in veterinary science at Universitas Airlangga, Indonesia. He completed his B.Sc. in biology and M.Sc. in vaccinology and immunotherapeutics at Universitas Airlangga, Indonesia. Currently, he is an awardee of the PMDSU Scholarship (Batch III) at Universitas Airlangga, Indonesia. His research projects are related to virology, bioinformatics, and molecular biology. His actual research focus is the application of molecular biology to unlock the SARS-CoV-2 genome in Indonesia.

Cite this article: Hartono, Suryawati B, Sari Y, Novika RGH, Avicena A, Maryani, et al. The Effect of Curcumin and Virgin Coconut Oil Towards Cytokines Levels in COVID-19 Patients at Universitas Sebelas Maret Hospital, Surakarta, Indonesia. Pharmacogn J. 2022;14(1): 216-225. 